\title{
Effects of breeder age and short-term temperature stimulation during incubation on performance, organ weight, and carcass yield in male and female broilers
}

\author{
Efeitos da idade da matriz e de alterações curtas de \\ temperatura de incubação no desempenho, peso dos \\ órgãos e rendimento de carcaça em frangos de corte \\ machos e fêmeas
}

Isabelle Naemi Kaneko 1*; Jovanir Inês Müller Fernandes²; Adrieli Braga de Cristo3; Flavia Kleszcz da Cruz ${ }^{4}$; Tatiana Carlesso dos Santos ${ }^{5}$

\section{Highlights}

The effects of breeder age and short-term temperature (STT) treatment were assessed. Breeder age and sex influenced relative organ weights and chick performance.

Chicks from 30- and 60-wk-old breeders in the STT group differed in yolk absorption.

STT stimulation improved yolk absorption in chicks from 60-wk-old breeders.

\begin{abstract}
Birds develop thermoregulatory control during the last days of incubation. Different temperature conditioning programs have been proposed to prepare broiler chicks for post-hatch life. This study aimed to investigate the effects of short-term temperature (STT) stimulation and breeder age on hatching performance, embryo development, yolk absorption, and post-hatch performance of male and female broilers. A $2 \times 2$ factorial completely randomized design was used, with two breeder ages (30 and 60 wk), two temperature incubation programs (control and STT), and 2,520 eggs per treatment. Eggs were distributed in two large-scale commercial incubators with a capacity of 120,960 eggs. The control group was subjected to a standard single-stage incubation program $\left(37.2-37.4^{\circ} \mathrm{C}\right)$, whereas the STT group was subjected to a temperature increment of $1^{\circ} \mathrm{C}$ for $4 \mathrm{~h}$ on embryonic days $16,17,18$, and 19 . Embryos were analyzed at 16 and 19 days of incubation, and chicks at hatch. At 19 days of incubation, STT conditioning

1 Veterinarian, Doctor in Animal Production, Universidade Federal de Paraíba, UFPB, Areia, PB, Brazil. E-mail: isabelle naemi@hotmail.com

2 Profa Dra, Department of Animal Science, Universidade Federal do Paraná, UFPR, Palotina, PR, Brazil. E-mail: jovanirfernandes@gmail.com

3 Veterinarian, Master in Animal Science, UFPR, Palotina, PR, Brazil. E-mail: adrielibcristo@gmail.com

${ }^{4}$ Animal Scientist, Universidade Estadual do Maringá, UEM, Maringá, PR, Brazil. E-mail: flaviakleszcz@hotmail.com

5 Profa Dra, Department of Animal Science, UEM, Maringá, PR, Brazil. E-mail: tcsantos@uem.br

* Author for correspondence
\end{abstract}

Received: Nov. 04, 2020 - Approved: Apr. 30, 2021 
resulted in lower yolk sac weight in embryos from 60-wk-old breeders and higher relative weight of the gastrointestinal tract in embryos from 30-wk-old breeders. At hatch, males had lower residual yolk weight, females had greater length, and chicks from 60-wk-old breeders subjected to STT had higher body weight and relative weight of the gastrointestinal tract. Eggs from 30-wk-old breeders showed higher fertility and hatchability and lower infertility, mortality, and second-grade chick percentages. Regarding performance, it was found that males had higher body weight from 7 to 42 days of age and higher whole leg yields. Females, on the other hand, had higher fat yields. Breeder age and sex influenced gastrointestinal tract development, carcass yield, and performance. A $1^{\circ} \mathrm{C}$ increase in incubation temperature for $4 \mathrm{~h}$ from days 16 to 19 of incubation affected yolk absorption and digestive tract development in chicks from 60-wk-old breeders without, however, influencing performance results.

Key words: Gastrointestinal tract. Hatch. Heat conditioning. Yolk.

\section{Resumo}

As aves desenvolvem o controle do sistema termorregulatório durante os últimos dias de incubação, dessa forma, diferentes programas temperatura de incubação têm sido descritos para preparar os pintos de corte para a vida pós-eclosão. Objetivou-se nesse estudo, estabelecer os efeitos de alterações curtas na temperatura de incubação e da idade da matriz no desempenho de eclosão, desenvolvimento embrionário, absorção da gema e desempenho pós-eclosão de frangos de corte machos e fêmeas. O delineamento experimental foi inteiramente casualizado em fatorial $2 \times 2$ com 2 idades de matriz (30 e 60 semanas) e 2 programas de incubação de temperatura, controle (CT) e grupo de treinamento de temperatura de curto prazo (STT) e 2.520 ovos em cada tratamento. Os ovos foram distribuídos em 2 incubadoras comerciais de grande escala com capacidade para 120.960 ovos. O grupo CT seguiu um programa de incubação de estágio único padrão $\left(37,2-37,4^{\circ} \mathrm{C}\right)$ e o STT teve um incremento em $+1^{\circ} \mathrm{C}$ por 4 hs nos dias 16,17 , 18 e 19 de incubação. Os embriões foram analisados aos 16 e 19 dias e pintinhos na eclosão. Aos 19 dias de incubação, embriões de matrizes com 60 semanas apresentaram menor peso do saco vitelino e embriões de matrizes com 30 semanas apresentaram maior porcentagem de trato gastrointestinal quando em STT. Na eclosão, os machos apresentaram menor vitelo residual, e as fêmeas apresentaram maior comprimento, pintinhos mais pesados e maior trato gastrointestinal quando originárias de matrizes de 60 semanas de idade e expostos ao STT. Na eclosão, os ovos com 30 semanas de idade apresentaram maior porcentagem de fertilidade e eclodibilidade e menor infertilidade, mortalidade e pintos de secunda categoria. No desempenho, os machos apresentaram maior peso corporal do $7^{\circ}$ ao $42^{\circ}$ dia e maiores valores de porcentagem de pernas e as fêmeas maiores valores de porcentagem de gordura. A idade das matrizes e o sexo influenciaram o desenvolvimento visceral, o rendimento de carcaça e o desempenho dos frangos de corte. $\mathrm{O}$ aumento de $1^{\circ} \mathrm{C}$ durante 4 horas entre os dias 16 e 19 de incubação afetou a absorção da gema e o trato digestivo em pintos de matrizes com 60 semanas de idade, sem refletir nos resultados de desempenho.

Palavras-chave: Trato gastrointestinal. Eclosão. Condicionamento térmico. Gema. 


\section{Introduction}

Incubation temperature is one of the most important physical factors determining or influencing chick embryo development and hatchability. The embryo cannot regulate its body temperature, which varies according to incubation temperature (Al-Rukibat, Al-Zghoul, Hananeh, Al-Natour, \& Abu-Basha, 2017). The pre-hatching period is critical because it will prepare embryos for internal and external pipping (Nangsuay et al., 2015).

Successful hatching depends on the completion of embryonic development, including maturation of endocrinal and neuronal systems (Shinder et al., 2011). Precocial birds, such as broilers, have a prenatal phase of thermoregulatory system development. This phase is characterized by endothermic reactions with low efficiency. Eggs absorb heat from the surrounding air during the first half of incubation, as embryonic temperature is lower than the incubator temperature; however, embryos lose heat during the second half of incubation as their metabolic rate and heat production increase (Tzschentke \& Rumpf, 2011).

During critical incubation periods, temperature can influence embryonic development with lasting effects (Tzschentke \& Tatge, 2013). Previous studies suggested that changes in incubation temperature at the end of embryonic development can induce epigenetic temperature adaptation (Al-Rukibat et al., 2017; Al-Zghoul, Sukker, \& Ababneh, 2019; Narinc, Erdogan, Tahtabicen, \& Aksoy, 2016; Saleh, Tarkhan, \& Al-Zghoul, 2020; Zaboli et al., 2017). This effect was also described as post-hatch heat conditioning (Zaboli et al., 2017). Thermal manipulation (exposure to high room temperatures) during the early post-hatch period was found to improve thermotolerance acquisition in poultry species (Tzschentke \& Rumpf, 2011).

In modern avian lineages, many factors may influence embryo metabolism, such as breeder age. Research has shown that embryo metabolism increases with breeder age, even with constant egg weights, indicating a true breeder age effect on the embryonic metabolism of modern broiler strains (Nangsuay et al., 2016).

The interaction effects of incubation temperature and breeder age on physiological embryo growth and hatchling quality are not well understood. Furthermore, the confounding effect of maternal breeder age on egg weight cannot be disregarded. This study aimed to examine the interaction effects of short-term temperature (STT) stimulation during the final period of incubation and breeder age on gastrointestinal tract development, yolk absorption, performance, and carcass yield of progeny.

\section{Material and Methods}

The experiment and all procedures involved were approved by the Animal Ethics Committee of the State University of Maringá, Maringá, Paraná State, Brazil (protocol number 062/2014).

Animals, experimental design, and incubation

Eggs from broiler breeders (Cobb $500^{\mathrm{TM}}$ ) were obtained from C.Vale Cooperativa Agroindustrial, Palotina, Paraná, Brazil. Breeders were fed on the same commercial diet 
and maintained under similar environmental conditions. The eggs were arranged on trays according to breeder age and stored for 4 days in an egg storage room at $18-20^{\circ} \mathrm{C}$ and $70 \%$ relative humidity. Two single-stage Jamesway ${ }^{\circledR}$ Platinum setters (capacity of 120,960 eggs each) were used to maintain the embryos at constant temperature. All eggs were incubated under standard singlestage conditions until embryonic (E) day 16. The incubator was set at $35.8-38.0{ }^{\circ} \mathrm{C}, 40 \%$ relative humidity, and $10,000 \mathrm{ppm} \mathrm{CO}_{2}$ until E10 and at 5,000 ppm CO from E11 to E21. Incubation procedures were carried out at C.Vale Cooperativa Agroindustrial, Palotina, Paraná, Brazil.

A total of 10,080 eggs were distributed in a $2 \times 2$ factorial randomized design with two breeder ages ( 30 and $60 \mathrm{wk}$ ) and two temperature treatments (control and STT). In the control group, a single-stage incubation program $\left(37.2-37.4^{\circ} \mathrm{C}\right)$ wasused fromE1 toE19. In the STT treatment, eggs were maintained at $37.2-37.4{ }^{\circ} \mathrm{C}$ and the temperature was increased to $38.2-38.4^{\circ} \mathrm{C}$ for $4 \mathrm{~h}$ on E16, E17, E18, and E19. For each treatment, 2,520 eggs were incubated, distributed in 15 replications of 168 eggs ( 4 trays of 42 eggs) each.

Yolk-free body weight, residual yolk weight, and relative organ weights

Yolk-free body weight was determined in eggs containing live embryos (1 egg per tray, 15 eggs per treatment), collected on E16 (before STT) and E19 (after 4 STT cycles). Embryos were removed and separated from the remaining egg content before weighing. Gastrointestinal tract and yolk sac weights were also determined.
At hatch, chicks were sexed by inspection of the wing feathers. Then, eight chicks per treatment were randomly analyzed for body weight, body length, yolk weight, and relative weights of the liver and gastrointestinal tract (proventriculus, gizzard, intestines, and pancreas). Chick length was measured by stretching the birds against a ruler and recording the length from the top of the beak to the top of the middle toe of the right foot. Chicks were euthanized by cervical dislocation to determine the residual yolk and gastrointestinal tract weights.

\section{Hatching performance}

The remaining unhatched eggs were opened and examined macroscopically for embryonic mortality, fertility, and infertility. The percentage hatchability of fertile eggs was calculated as the number of saleable chicks hatched per 100 fertile eggs. Unhealthy chicks (embryonic anomalies, leg and navel problems) were classified as second-grade chicks.

\section{Post-hatch performance}

For performance assessment, a total of 1,080 chicks were sexed and housed under temperature-controlled conditions in the Experimental Shed of the Federal University of Paraná, Palotina campus, Brazil. The shed is equipped with an evaporative cooling system (15 $\mathrm{m}$ long and $12 \mathrm{~m}$ wide) and divided into 32 pens of $3.75 \mathrm{~m} 2$. The design was completely randomized in a $2 \times 2 \times 2$ factorial, with two breeder ages (30 and $60 \mathrm{wk}$ ), two incubation temperature programs (control and STT), and two sexes (male and female), totaling 8 
treatments and 4 replicates of 34 birds per treatment.

Water and commercial feed were supplied ad libitum. From 1 to 42 days of age, birds were weighed weekly and the following performance variables were determined: body weight, weight gain, feed intake, and feed conversion.

At 42 days of age, two birds per pen were used for determination of carcass and cut yields. Birds were anesthetized with sodium pentobarbital (20 $\mathrm{mg} \mathrm{kg}^{-1}$ intravenously) and, after confirmation of immobilization, culled by cervical dislocation. Carcass yield was determined using the weight of eviscerated carcass without feet, head, and abdominal fat and the individual body weight before slaughter. Breast yield (including skin and bones) and whole leg yield (including thigh and drumstick with bones and skin) were also determined.

\section{Statistical analysis}

Statistical analysis was performed using Statistical Analysis Software (Statistical Analysis System Institute [SAS Institute], 2012). Data were tested for normality of distribution and homogeneity of variance. Analysis of variance was carried out using PROC GLM, and, when the $P$-value was significant $(P \leq$
0.05) for the interaction term, the LS MEANS procedure was used to compare means. Statistical significance was set at $P<0.05$ unless otherwise stated.

\section{Results and Discussion}

Yolk-free body weight, residual yolk weight, and relative organ weights

On E16, temperature treatments had not yet been applied; thus, we only report the main effects of breeder age. Eggs from 60-wk-old breeders had higher values of body weight $(P<0.01)$ and residual yolk weight $(P<0.01)$ than eggs from 30 -wk-old breeders (Table 1). Albumen and yolk are used for energy production. Egg yolk is the main nutritional supply, responsible for about $90 \%$ of the total energy requirement; it is oxidized to provide energy for development and growth (Nangsuay, Meijerhof, Ruangpanit, Kemp, \& Vander Brand, 2013). Breeder age is known to mainly influence egg, embryo, and yolk weights, as widely studied and described in the literature. An increase in egg size is associated with a decrease in egg production, which is partially caused by a reduction in the number of follicles that reach the final phase of maturation (Nangsuay et al., 2013; Nangsuay, Ruangpanit, Meijerhof, \& Attamangkune, 2011). 


\section{Table 1}

Effects of breeder age, incubation temperature, sex, and their interactions on chick length at hatch and on yolk-free body weight, residual yolk weight, and relative weights of the liver and gastrointestinal tract before (on embryonic day 16, E16) and after (on embryonic day 19, E19) short-term temperature stimulation (STT) (E16 and E19, $n=15$; hatch, $n=16,8$ males and 8 females)

\begin{tabular}{|c|c|c|c|c|c|c|c|c|}
\hline \multirow[t]{2}{*}{ Parameter } & \multirow[t]{2}{*}{ Age } & \multicolumn{2}{|c|}{ Breeder age } & \multicolumn{2}{|c|}{$\begin{array}{l}\text { Incubation } \\
\text { temperature }\end{array}$} & \multicolumn{2}{|c|}{ Sex } & \multirow[t]{2}{*}{ SEM $^{2}$} \\
\hline & & $30 w k$ & $60 w k$ & Control & STT & Male & Female & \\
\hline Chick length (cm) & Hatch & 18.03 & 18.38 & 18.24 & 18.23 & 18.26 & 18.21 & 1.71 \\
\hline \multirow{3}{*}{ Yolk-free body weight (g) } & E16 & $17.51^{b}$ & $18.78^{a}$ & - & - & - & - & 2.59 \\
\hline & E19 & $31.36^{b}$ & $33.75^{a}$ & 32.81 & 32.29 & - & - & 3.38 \\
\hline & Hatch & $44.72^{b}$ & $48.97^{\mathrm{a}}$ & $48.20^{\mathrm{a}}$ & $45.49^{b}$ & 47.56 & 46.14 & 7.99 \\
\hline \multirow{3}{*}{ Residual yolk weight (g) } & E16 & $12.86^{b}$ & $16.81^{\mathrm{a}}$ & - & - & - & - & 5.32 \\
\hline & E19 & $10.69^{b}$ & $12.91^{\mathrm{a}}$ & 11.97 & 11.61 & - & - & 5.29 \\
\hline & Hatch & $4.56^{b}$ & $5.52^{a}$ & 5.28 & 4.81 & $5.40 a$ & $4.71 b$ & 3.24 \\
\hline \multirow{3}{*}{$\begin{array}{l}\text { Relative weight of the } \\
\text { liver (\%) }\end{array}$} & E16 & 0.60 & 0.59 & - & - & - & - & 0.16 \\
\hline & E19 & 1.19 & 1.15 & 1.19 & 1.15 & - & - & 0.28 \\
\hline & Hatch & $2.69^{b}$ & $2.87^{a}$ & 2.77 & 2.77 & 2.72 & 2.83 & 0.74 \\
\hline \multirow{3}{*}{$\begin{array}{l}\text { Relative weight of the } \\
\text { gastrointestinal } \text { tract }^{3}(\%)\end{array}$} & E16 & 1.59 & 1.53 & - & - & - & - & 0.58 \\
\hline & E19 & $4.36^{a}$ & $4.02^{b}$ & 4.25 & 4.14 & - & - & 0.18 \\
\hline & Hatch & 11.69 & 11.81 & 11.54 & 11.96 & 11.48 & 12.01 & 2.87 \\
\hline
\end{tabular}

For residual yolk weight on E19, significant interaction effects of breeder age and incubation temperature $(P=0.02)$ were observed. Control embryos (incubated at 37.2-37.4 ${ }^{\circ} \mathrm{C}$ ) collected from 60-wk-old breeders had higher residual yolk weight than those from 30-wk-old breeders (Figure 1A). At hatch, a triple interaction effect was observed on residual yolk weight $(P<0.01)$ : males from 60-wk-old breeders subjected to control incubation temperatures had higher residual yolk weight than STT-conditioned males (Figure 1B). This result indicates that embryos from older breeders had higher yolk absorption after 19 days of incubation when subjected to stress. A previous study demonstrated that, although eggs from older breeders have a greater amount of yolk, the amount of energy transferred to the embryo (i.e., yolk absorption) is greater. The amount of energy transferred to the chick depends on the amount of energy available for transfer (Nangsuay et al., 2016). However, our results showed that eggs from older breeders incubated at constant temperatures showed similar yolk absorption to eggs from younger breeders, despite the greater amount of yolk available. 
(A)

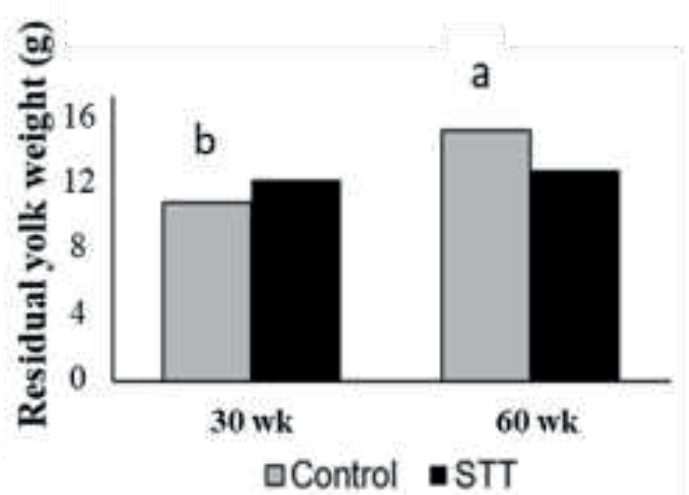

(B)

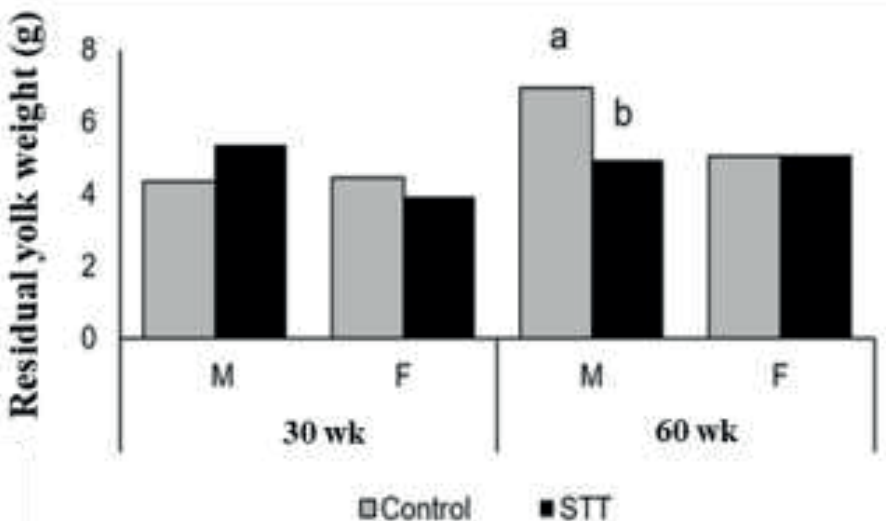

Figure 1. (A) Interaction effects of breeder age and incubation temperature on residual yolk weight at 19 days of incubation. (B) Interaction effects of breeder age, incubation temperature, and sex on residual yolk weight at hatch. Control, 37.2-37.4 ${ }^{\circ} \mathrm{C}$; STT, short-term temperature stimulation (38.2$38.4^{\circ} \mathrm{C}$ during $4 \mathrm{~h}$ on embryonic days 17,18 , and 19$)$.

The last week of incubation is when most of the vitelline reserves are absorbed, particularly lipid contents, which are subject to oxidation. This period is also characterized by maturation of the chorioallantoic membrane. Two to three days before hatching, there is an increase in the absorptive area of the vitelline membrane, probably due to changes in the germ layer and proliferation of absorbent cells (Yadgary, Kedar, Adepeju, \& Uni, 2013).

An increase in incubation temperature in the week prior to hatching increases the production of metabolic heat by embryos, resulting in greater use of $\mathrm{O}_{2}$. In general, during the pre-hatching period, the demand for $\mathrm{O}_{2}$ exceeds the capacity of gas exchange through shell pores and the chorioallantoic membrane, thereby decreasing the metabolic rate. This leads to a reduction in metabolic heat rate in the last week of incubation (up to E18) when eggs are under high-temperature conditions $\left(38.9^{\circ} \mathrm{C}\right)$ compared with normal temperatures $\left(37.8^{\circ} \mathrm{C}\right)$; this effect is not observed in the first two weeks of incubation (Tzschentke \& Rumpf, 2011).

The relative weight of the gastrointestinal tract on 19E was significantly influenced by the interaction effects of breeder age and incubation temperature (Figure 2A). The parameter was higher in embryos from 30-wk-old breeders subjected to STT conditioning $(P=0.01)$. Significant interaction effects were also observed at hatch $(P=0.02)$ : chicks from eggs of 60-wk-old breeders and subjected to STT stimulation during incubation had larger gastrointestinal tracts (Figure 2B).

At hatch, significant Breeder age $\times$ Sex interaction effects were found on chick length ( $p<0.05$ ). Females from 60 -wk-old breeders were longer than males (Figure 3). Main effects of breeder age and sex on chick body weight were also observed. Chicks from 60-wkold breeders were heavier than chicks from 30-wk-old breeders, and chicks subjected to 
normal incubation temperatures were heavier than those subjected to STT stimulation (Table 1). These results demonstrated that the greater growth of chicks from older breeders was likely due to their superior yolk absorption at this age. Breeder age influences the absorption pattern and fatty acid composition of yolk. In a previous study, the residual yolk of embryos from breeders aged over 56 wk had a lower content of oleic and arachidonic acids than the residual yolk of embryos from 36-wkold breeders (Şahan, Ipek, \& Sozku, 2014).

\section{(A)}

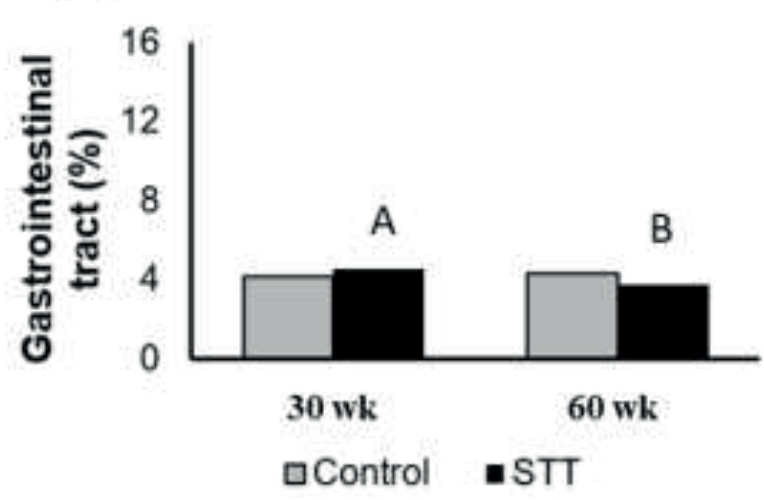

(B)

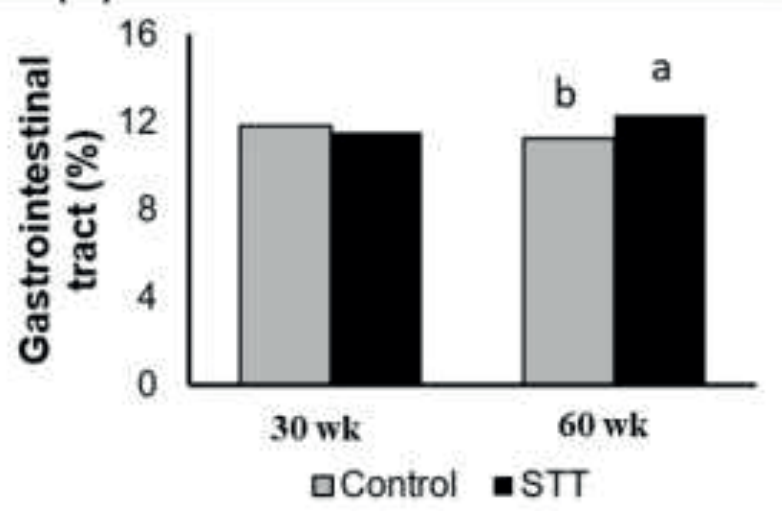

Figure 2. Interaction effects of breeder age and incubation temperature on the relative weight of the gastrointestinal tract (proventriculus, gizzard, intestines, and pancreas) (A) at 19 days of incubation and (B) at hatch. Control, 37.2-37.4 ${ }^{\circ} \mathrm{C}$; STT, short-term temperature stimulation (38.2$38.4^{\circ} \mathrm{C}$ during $4 \mathrm{~h}$ on embryonic days 17,18 , and 19 ).

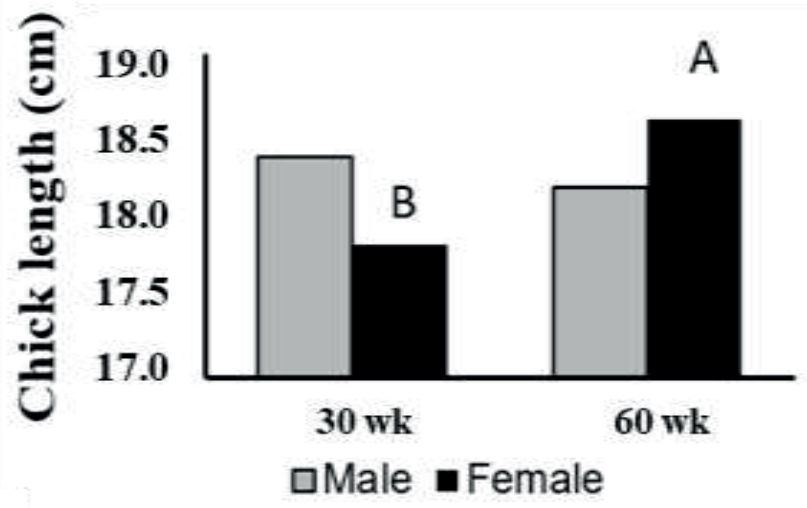

Figure 3. Interaction effects of breeder age and sex on chick length at 1 day of age. 
There is evidence that the change from poikilothermy to homeothermy in chicks may be influenced by yolk lipid composition, indicating that the regulation of heat production during incubation and the first days of life differ between chicks from young breeders and those from older breeders. We observed an interaction effect between breeder age and incubation temperature on the relative weight of the gastrointestinal tract at hatch. Chicks from 60-wk-old breeders showed the best development when subjected to STT conditioning. These findings suggest that an increase in yolk content in embryos subjected to thermal stimulation during incubation could modify intestinal development (Weytjens, Meijerhof, Buyse, \& Decuypere, 1999). Yolk uptake during the embryonic period is important because it improves intestinal quality and intestinal villus structure in the post-hatch period (Maatjens et al., 2016).

Although histomorphometric analysis of gastrointestinal tract segments was not performed, the difference in relative weights of the gastrointestinal tract between STT and control chicks suggests that different incubation protocols may need to be applied depending on breeder age. Embryos use egg components for development until hatching. After using albumen and amniotic fluid contents, chicks begin to use the yolk as the sole source of nutrition. Yolk nutrients are transported through the yolk sac to the vascular system; use of the yolk sac can be one of the limiting factors for embryonic development (Gous, 2010; Nangsuay et al.,
2011). Thus, an increase in yolk size and yolk absorption as a function of breeder age may affect early embryonic development (Nangsuay et al., 2011). If the yolk content is not available, the embryo begins to degrade muscle protein, which can restrict its growth after hatching, resulting in birds with poor muscle development (Uni \& Ferket, 2010). Our results also demonstrated that females from older breeders had greater body lengths than females from younger breeders. Such a result may be due to the greater yolk absorption seen in birds from 60-wk-old breeders.

\section{Hatching performance}

The hatching performance of incubated eggs was analyzed using probability, and results are described in Table 2. No significant interaction effects were observed. The main effects of breeder age were significant for fertility $(P<0.01)$, infertility $(P<0.01)$, hatchability $(P<0.01)$, mortality $(P$ $<0.01)$, and second-grade chicks $(P=0.004)$. Fertility and hatchability were higher in eggs from 30-wk-old breeders, whereas infertility, mortality, and second-grade chicks were higher in eggs from 60-wk-old breeders. In general, egg quality decreased with increasing breeder age, attributed to the quality of the shell and albumen. The low shell and albumen qualities of eggs from older breeders result in greater weight loss during incubation and, consequently, higher embryonic mortality (Şahan et al., 2014). 


\section{Table 2}

Fertility, infertility, hatchability, mortality, and second-grade chick percentages as a function of breeder age, incubation temperature, and their interaction, estimated by probabilistic models ( 15 replications of 168 eggs per treatment; $n=2,520$ eggs per treatment).

\begin{tabular}{|c|c|c|c|c|c|}
\hline \multirow{2}{*}{ Variable $^{1}$} & \multicolumn{2}{|c|}{ Breeder age } & \multicolumn{2}{|c|}{ Incubation temperature ${ }^{2}$} & \multirow[t]{2}{*}{$\mathrm{SEM}^{3}$} \\
\hline & 30 wk & $60 w k$ & Control & STT & \\
\hline Fertility (\%) & $88.96^{a}$ & $80.10^{b}$ & 84.23 & 84.83 & 3.44 \\
\hline Infertility (\%) & $5.98^{\mathrm{b}}$ & $10.82^{\mathrm{a}}$ & 8.87 & 7.96 & 3.44 \\
\hline Hatchability (\%) & $94.02^{\mathrm{a}}$ & $89.18^{b}$ & 91.16 & 92.04 & 3.23 \\
\hline Mortality (\%) & $4.63^{b}$ & $8.02^{\mathrm{a}}$ & 6.24 & 6.41 & 2.89 \\
\hline Second-grade chicks (\%) & $0.43^{b}$ & $1.05^{\mathrm{a}}$ & 0.69 & 0.80 & 0.95 \\
\hline
\end{tabular}

a,b Means within a row followed by different superscript letters are significantly different by Tukey's test $(P<0.05)$.

${ }^{1}$ Probabilities were calculated by the equation $Y=\exp (\beta) /[1+\exp (\beta)] \times 100$.

${ }^{2}$ Control, constant incubation temperature of $37.2-37.4^{\circ} \mathrm{C}$; short-term temperature stimulation (STT), incubation temperature increased to $38.2-38.4^{\circ} \mathrm{C}$ for $4 \mathrm{~h}$ on embryonic days 17,18 , and 19 .

${ }^{3}$ SEM, standard error of mean.

\section{Post-hatch performance}

Broiler performance variables were not influenced by STT conditioning (Table 3). Body weight, weight gain, and feed intake were significantly higher in broilers from 60-wk-old breeders $(P<0.05)$ until 21 days of age. Body weight, weight gain, feed intake, and feed conversion were influenced by sex. Males had higher body weight and weight gain than females from 7 to 42 days of age $(p<0.05)$. Males also had greater feed intake, but females had higher feed conversion rates than males from 1 to 42 days of age. These results can be attributed to the larger size of eggs from older breeders and are consistent with the results of previous studies showing that eggs from older breeders have a higher yolk/albumen ratio (Nangsuay et al., 2013; Nangsuay et al., 2011; Şahan et al., 2014). Sexual dimorphism also plays an important role in the observed differences, highlighting the importance of male sex hormones in protein deposition. 
Table 3

Effects of breeder age, incubation temperature, sex, and their interaction on the post-hatch performance (body weight, weight gain, feed intake, and feed conversion ratio) of broilers $(n=8)$

\begin{tabular}{|c|c|c|c|c|c|c|c|}
\hline \multirow{2}{*}{ Age } & \multicolumn{2}{|c|}{ Breeder age } & \multicolumn{2}{|c|}{ Incubation temperature $^{1}$} & \multicolumn{2}{|c|}{ Sex } & \multirow{2}{*}{$\mathrm{SEM}^{2}$} \\
\hline & 30 wk & 60 wk & Control & $\overline{\text { STT }}$ & Male & Female & \\
\hline \multicolumn{8}{|c|}{ Body weight (g) } \\
\hline 1 & $43.5^{b}$ & $49.1^{\mathrm{a}}$ & 46.3 & 46.2 & 46.18 & 46.4 & 1.6 \\
\hline 7 & $182.4^{\mathrm{b}}$ & $204.9^{a}$ & 193.5 & 193.8 & $196.1^{\mathrm{a}}$ & $191.2^{b}$ & 8.6 \\
\hline 21 & $997.3^{b}$ & $1054.4^{\mathrm{a}}$ & 1023.6 & 1028.0 & $1070.5^{a}$ & $981.1^{b}$ & 77.3 \\
\hline 42 & 2782.8 & 2837.3 & 2823.6 & 2796.6 & $3040.4^{a}$ & $2579.7^{b}$ & 291.6 \\
\hline \multicolumn{8}{|c|}{ Weight gain (g) } \\
\hline $1-7$ & $138.8^{b}$ & $155.2^{\mathrm{a}}$ & 147.1 & 146.9 & $149.5^{\mathrm{a}}$ & $144.5^{b}$ & 8.2 \\
\hline $1-21$ & $931.5^{\mathrm{b}}$ & $990.1^{a}$ & 955.8 & 965.8 & $1006.8^{a}$ & $914.8^{b}$ & 98.3 \\
\hline $1-42$ & 2596.4 & 2691.7 & 2649.0 & 2639.1 & $2858.7^{a}$ & $2429.4^{b}$ & 347.8 \\
\hline \multicolumn{8}{|c|}{ Feed intake (g) } \\
\hline $1-7$ & $157.7^{\mathrm{b}}$ & $177.9^{\mathrm{a}}$ & 168.2 & 167.4 & 165.53 & 170.0 & 18.4 \\
\hline $1-21$ & $1212.5^{b}$ & $1287.4^{\mathrm{a}}$ & 1252.2 & 1247.6 & $1280.1^{\mathrm{a}}$ & $1219.8^{b}$ & 164.6 \\
\hline $1-42$ & 4170.6 & 4293.6 & 4213.8 & 4250.4 & $4424.0^{a}$ & $4040.3^{b}$ & 484.7 \\
\hline \multicolumn{8}{|c|}{ Feed conversion ratio $\left(\mathrm{g} \mathrm{g}^{-1}\right)$} \\
\hline $1-7$ & 1.14 & 1.15 & 1.14 & 1.14 & $1.11^{\mathrm{b}}$ & $1.18^{a}$ & 0.13 \\
\hline $1-21$ & 1.31 & 1.29 & 1.30 & 1.30 & 1.29 & 1.30 & 0.05 \\
\hline $1-42$ & 1.61 & 1.60 & 1.60 & 1.62 & $1.55^{\mathrm{b}}$ & $1.66^{a}$ & 0.18 \\
\hline
\end{tabular}

a.b Means within a row followed by different superscript letters are significantly different by Tukey's test $(P<0.05)$.

1 Control, constant incubation temperature of $37.2-37.4{ }^{\circ} \mathrm{C}$; short-term temperature stimulation (STT), incubation temperature increased to $38.2-38.4^{\circ} \mathrm{C}$ for $4 \mathrm{~h}$ on embryonic days 17,18 , and 19 .

${ }^{2} \mathrm{SEM}$, standard error of mean.

STT stimulation did not influence broiler performance. The lack of effects may be a result of the period in which eggs were exposed to thermal stimulation. Wijnen et al. (2020) obtained similar results in chick quality and performance; eggs were incubated at $37.8-38.8^{\circ} \mathrm{C}$ in the second and third weeks, and no differences were observed between treatments.
Slaughter performance at 42 days of age

The results of carcass analysis are presented in Table 4. There was an interaction effect of breeder age and sex on body weight. Males from eggs of 30- and 60-wk-old breeders had higher body weight than females from 30- and 60-wk-old breeders (Figure 4).

Sex influenced whole leg and fat yields. Males had higher whole leg yields than females $(P<0.05)$, whereas females 
had greater fat yield than males (Table 4), in agreement with previous studies (Collin et al., 2007; Leksrisompong, Romero-Sanchez, Plumstead, Brannan \& Brake, 2007).

Tzschentke and Halle (2009) showed that, compared with normal incubation (37.2$37.4{ }^{\circ} \mathrm{C}$ ) and chronic warm incubation (38.2-
$38.4{ }^{\circ} \mathrm{C}$ ), STT stimulation (increase of $1{ }^{\circ} \mathrm{C}$ for $2 \mathrm{~h}$ each day, starting from E18 until hatching) improved hatchability, feed intake, feed conversion, and body weight at slaughter, especially in male broilers. In the current study, breeder age and incubation temperature did not influence slaughter performance.

Table 4

Effects of breeder age, incubation temperature, sex, and their interactions on the slaughter performance (body weight and carcass, leg, breast, and fat yields) of broilers at 42 days of age $(n=8)$

\begin{tabular}{|ccccccccc}
\multirow{2}{*}{ Variable } & \multicolumn{2}{c}{ Breeder age } & \multicolumn{2}{c}{$\begin{array}{l}\text { Incubation } \\
\text { temperature }\end{array}$} & \multicolumn{2}{c}{ Sex } & Mean & \multirow{2}{*}{ SEM $^{1}$} \\
\cline { 2 - 7 } & $30 \mathrm{wk}$ & $60 \mathrm{wk}$ & Control & STT & Male & Female & & \\
\hline Body weight (g) & 2883.56 & 2937.50 & 2923.63 & 2897.44 & $3148.44^{\mathrm{a}}$ & $2672.63^{\mathrm{b}}$ & 2910.53 & 346.47 \\
Carcass yield (\%) $^{2}$ & 75.34 & 75.58 & 75.59 & 75.33 & 75.79 & 75.13 & 75.46 & 5.12 \\
Leg yield (\%) $^{2}$ & 26.25 & 26.18 & 26.00 & 26.44 & $26.88^{\mathrm{a}}$ & $25.53^{\mathrm{b}}$ & 26.22 & 2.83 \\
Breast yield (\%) $^{2}$ & 36.69 & 36.89 & 37.00 & 36.58 & 36.82 & 36.77 & 36.79 & 4.40 \\
\hline Fat yield (\%) & 2.43 & 2.54 & 2.39 & 2.58 & $2.00^{\mathrm{b}}$ & $2.98^{\mathrm{a}}$ & 2.48 & 1.58 \\
\hline
\end{tabular}

a,b Means within a column followed by different superscript letters differ by Tukey's test $(P<0.05)$.

1 Control, incubation constant temperature of $37.2-37.4{ }^{\circ} \mathrm{C}$; short-term temperature stimulation (STT), incubation temperature increased to $38.2-38.4^{\circ} \mathrm{C}$ for $4 \mathrm{~h}$ on embryonic days 17,18 , and 19.

${ }^{2}$ Carcass yield was calculated as the ratio of the eviscerated carcass weight (without feet, head, and abdominal fat) to the body weight of birds, determined individually before slaughter. The yield of primal cuts was determined using the weight of the meat with skin and bones.

${ }^{3}$ SEM, standard error of mean.

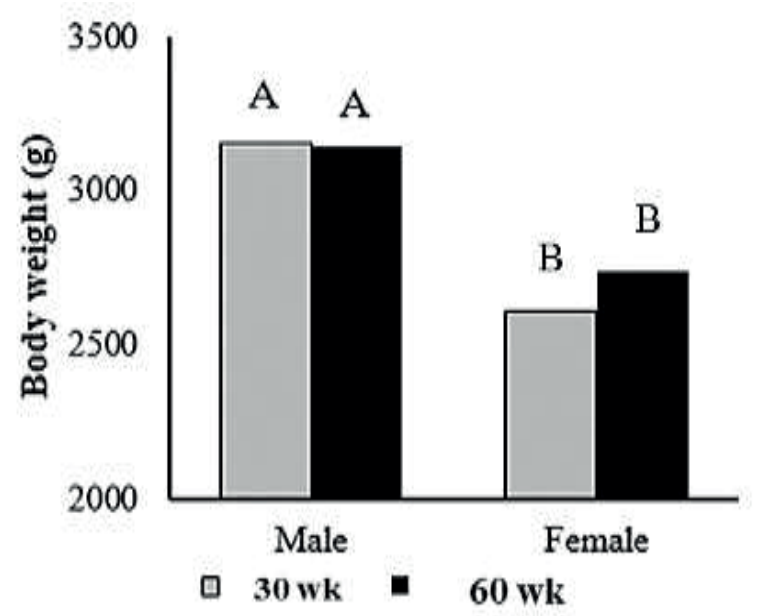

Figure 4. Interaction effects of breeder age and sex on body weight at 42 days of age. 


\section{Conclusions}

Breeder age and sex influence gastrointestinal tract development, carcass yield, and performance in broilers. Yolk sac absorption profiles differ between chicks from 30- and 60-wk-old breeders subjected to STT stimulation during incubation. STT conditioning improves yolk absorption in chicks from 60-wk-old breeders. Thus, changes in incubation temperature, such as those made in this study, are not indicated.

\section{Acknowledgments}

The authors are thankful to C.Vale Cooperativa Agroindustrial for providing the facilities, eggs, and diets used in this study. The authors received grants from the Brazilian National Council for Scientific and Technological Development (CNPq). This study was financed in part by the Brazilian Federal Agency for Support and Evaluation of Graduate Education (CAPES, Finance Code 001).

\section{Disclosure statement}

No potential conflict of interest was reported by the authors.

\section{References}

Al-Rukibat, R. K., Al-Zghoul, M. B., Hananeh, W. M., Al-Natour, M. Q., \& Abu-Basha, E. A. (2017). Thermal manipulation during late embryogenesis: effect on body weight and temperature, thyroid hormones, and differential white blood cell counts in broiler chickens. Poultry Science, 96(1), 234-240. doi: 10.3382/ps/pew298
Al-Zghoul, M. B., Sukker, H., \& Ababneh, M. M. (2019). Effect of thermal manipulation of broiler embryos on the response to heatinduced oxidative stress. Poultry Science, 98(2), 991-1001. doi: 10.3382/pspey 379

Collin, A., Berri, C., Tesseraud, S., Requena Rodon, F. E., Skiba-Cassy, S., Crochet, S., Yahav, S. (2007). Effects of thermal manipulation during early and late embryogenesis on thermotolerance and breast muscle characteristics in broiler chickens. Poultry Science, 86(5), 795800. doi: $10.1093 / p s / 86.5 .795$

Gous, R. M. (2010). Nutritional limitations on growth and development in poultry. Livestock Science, 130(1-3), 25-32. doi: 10.1016/j.livsci.2010.02.007

Leksrisompong, N., Romero-Sanchez, H., Plumstead, P. W., Brannan, K. E., \& Brake, J. (2007). Broiler incubation. 1. effect of elevated temperature during late incubation on body weight and organs of chicks. Poultry Science, 86(12), 26852691. doi: 10.3382/ps.2007-00170

Maatjens, C. M., Van Roovert-Reijrink, I. A. M, Engel, B., Van der Pol, C. W., Kemp, B., \& Van den Brand, H. (2016). Temperature during the last week of incubation. I. Effects on hatching pattern and broiler chicken embryonic organ development. Poultry Science, 95(4), 956-965. doi: 10.3382/ps/ pev447

Nangsuay, A., Meijerhof, R., Ruangpanit, Y., Kemp, B., \& Van den Brand, H. (2013). Energy utilization and heat production of embryos from egg originating from young and old broiler breeder breeders. Poultry Science, 92(2), 474-482. doi: 10.3382/ps. 2012-02643 
Nangsuay, A., Meijerhof, R., Van den Anker I., Heetkamp, M. J. W., Souza Morita, V. de, Kemp, B., \& Van den Brand, H. (2016). Effects of breeder age, broiler strain, and eggshell temperature on development and physiological status of embryos and hatchlings. Poultry Science, 95(7), 16661679. doi: 10.3382/ps/pew080

Nangsuay, A., Meijerhof, R., Van den Anker, I., Heetkamp, M. J. W., Kemp, B., \& Van den Brand, H. (2015). Development and nutrient metabolism of embryos from two modern broiler strains. Poultry Science, 94(10), 2546-2554. doi: 10.3382/ps/pev 234

Nangsuay, A., Ruangpanit, Y., Meijerhof, R., \& Attamangkune, S. (2011). Yolk absorption and embryo development of small and large eggs originating from young and old breeder hens. Poultry Science, 90(11), 2648-2655. doi: 10.3382/ps.2011-01415

Narinc, D., Erdogan, S., Tahtabicen, E., \& Aksoy, T. (2016). Effects of thermal manipulations during embryogenesis of broiler chickens on developmental stability, hatchability and chick quality. Animal, 10(8), 13281335. doi: $10.1017 / S 1751731116000276$

Şahan, U., Ipek, A., \& Sozcu, A. (2014). Yolk sac fatty acid composition, yolk absorption, embryo development, and chick quality during incubation in eggs from young and old broiler breeders. Poultry Science, 93(8), 2069-2077. doi: 10.3382/ps.201303850

Saleh, K. M. M., Tarkhan, A. H., \& Al-Zghoul, M. B. (2020). Embryonic thermal manipulation affects the antioxidant response to post-hatch thermal exposure in broiler chickens. Animals, 10(126), 1-14. doi: 10. 3390/ani10010126
Statistical Analysis System Institute (2012). SAS/STAT 9.4 User's guide. Cary, NC: SAS Institute Inc.

Shinder, D., Rusal, M., Giloh, M., Druyan, S., Piestun, Y., \& Yahav, S. (2011). Improvement of cold resistance and performance of broilers by acute cold exposure during late embryogenesis. Poultry Science, 90(3), 633-641. doi: 10.3382/ps.2010-01 089

Tzschentke, B., \& Halle, I. (2009). Influence of temperature stimulation during the last 4 days of incubation on secondary sex ratio and later performance in male and female broiler chicks. British Poultry Science, 50(5), 634-640. doi: 10. 1080/00071660903186570

Tzschentke, B., \& Rumpf, M. (2011). Embryonic development of endothermy. Respiratory Physiolology and Neurobiology, 178(1), 97-107. doi: 10.1016/j.resp.2011.06.004

Tzschentke, B., \& Tatge, S. (2013). Incubação circadiana ${ }^{{ }_{-}} \quad$ "Treinamento térmico" embrionário para a robustez em aves. In M. Macari (Ed.), Manejo da incubação (pp. 136-142). Jaboticabal: Facta.

Uni, J., \& Ferket, P. (2010). Alimentação inovo: impacto sobre o desenvolvimento intestinal, teor corporal de energia e desempenho. Anais da Conferência Facta 2010 de Ciência e Tecnologia Avícola, Santos, SP, Brasil.

Weytjens, S., Meijerhof, R., Buyse, J., \& Decuypere, E. (1999). Thermoregulation in chicks originating from breeder flocks of two different ages. Journal of Applied Poultry Research, 8(2), 139-145. doi: 10.1093/ japr/8.2.139 
Wijnen, H. J., Molenaar, R., Van RoovertReijrink, I. A. M., Van der Pol, C. W., Kemp, B., \& Van den Brand, H. (2020). Effects of incubation temperature pattern on broiler performance. Poultry Science, 99(8), 3897-3907. doi: 10.1016/j.psj. 2020.05.010

Yadgary, L., Kedar, O., Adepeju, O., \& Uni, Z. (2013). Changes in yolk sac membrane absorptive area and fat digestion during chick embryonic development. Poultry Science, 92(6), 1634-1640. doi: 10.3382/ ps.2012-02886
Zaboli, G. R., Rahimi, S., Shariatmadari, F., Torshizi, M. A. K., Baghbanzadeh, A., \& Mehri, A. M. (2017). Thermal manipulation during pre and post-hatch on thermotolerance of male broiler chickens exposed to chronic heat stress. Poultry Science, 96(2), 478-485. doi: 10.3382/ps/ pew344 
